\title{
An Evaluation of Application of Zakat for Poverty Alleviation among Muslims in Iba Housing Estate, Lagos State, Nigeria
}

\author{
Kabir Olawale Paramole \\ Department of Religions and Peace Studies, Lagos State University
}

\begin{abstract}
No Islamic Scholar in Lagos State will deny the fact that, zakat is the most abandoned out of the five pillars of Islam. Even, the few affluent Muslims who pay attention to it may not be perfect in its annual deduction and disbursement. This study assessed and evaluated the application of zakat as employed by Iba Housing Estate Zakat Agency for Poverty Alleviation with a view of determining its success in ameliorating poverty among Muslims in the community. Using field and library-based researches; it has been found that the agency has recorded a very little success in its few years of operation with the small fund available to operate upon. Its best practices include, rendering of support and assistance to the needy and the poor challenged with health problems, widows, orphans etc. within the area. However, the sources of income of the agency are circumscribed to only zakat payment which cannot create an avenue for outstanding impacts. The study recommends among others, that in order to contribute immensely to reduce poverty, as well as to be able to cover the needs of the poor Muslims in the community, the agency should diversify its efforts in getting more funds from other lawful sources, groups, agencies and wealthy individuals who have been showing interest in supporting their cause.
\end{abstract}

Keywords: Poverty-Alleviation; Zakat-Agency; Iba-Housing; Nisāb; Lagos

\section{INTRODUCTION}

It is not a gainsaying the fact that in the 21st century Nigeria, economic recession has become the order of the day. The key features of Nigeria poverty challenge crystallize in the poor record of economic growth, high inequality access to basic social services which result in low level of human resource development as well as low agricultural development. The added difficulty in fighting poverty in Nigeria is the widening income gap between the rich and the poor.

All the poverty alleviation measures adopted in Nigeria from the Operation Feed the Nation introduced in 1979 to the National Poverty Eradication Programme (NAPEP) have not really succeeded in reducing the overall picture of poverty in Nigeria (Mikail, 1996: 200). They can only have a little impact on a few members of Nigeria society because the financial resources available for their implementation are scarce.

In effects, the Islamic economic system offers fundamental and comprehensive approaches to poverty alleviation through the institution of zakat (Obligatory charity), Sadaqat (voluntary alms), among others, particularly in countries where Islamic law is not strictly in use, the only means of funding Islam is zakat. Nigeria muslim ummah is injuriously afflicted by two implacable disasters, namely ignorance and poverty. These two disasters are closely interwoven that 
solution to one can easily proffer solution to the other.

The issue of wealth and its management is a significant chapte $0 \mathrm{r}$ of human life that covers about two third of Islam, there can be no meaningful observance of fasting during Ramadan, performing of Hajj rites, proper upbringing of children, acquisition of knowledge, contribution to the social well being of the needy and orphans in the society without due consideration for wealth. Thus, in order to bring the virtue of love, security and self respect, Allāh introduced the institution of zakat as a means of redistribution of wealth and establishment of cordiality in human interrelationship. This means that no institution in Islam has brought so much harmony to human society as zakat.

Also, of the five pillars of Islam only zakat affects other people directly, as it plays central role that the other four pillars only rotate around its axis because it is divinely designed to serve a special purpose in the social lives of the Muslim ummah. However, this paper covers the attitudes of Muslims in Iba Local Council Development Area (LCDA) in Lagos State, Nigeria to poverty alleviation through the institution of zakat among them. It discusses definition of zakat; the significance of zakat in Islam; administration of zakat in Islam; administration of zakat in Nigeria, Lagos State and Iba LCDA; challenges besetting the payment, collection and distribution of zakat in Iba LCDA; assessment of Iba Housing Estate Agency (IHEA) on collection and distribution of zakat for poverty alleviation with recommendations and conclusion.

\section{DEFINITION OF ZAKAT}

Literally, zakat is an Arabic word, which connotes purification (Ritchie, 1976: 1676), as embodied in the following verses of the Qur'an:

"Truly he succeeds that
purifies it". (Qur'an 91:9)

It also means to sanctify. The Qur'ān says:

"Take sadaqat charity from their wealth in order to purify and sanctify them..." (Qur'an 9:103)

As a legal terminology, the concept of zakat, being the cornerstone of the financial edifice outlined in the Qur'an, calls for an explanation. Despite the fact that the Qur'an mentions it frequently, it gives no guidance as to its definition or application. This is one of the instances in which tradition and jurisprudential reasoning have been resorted to for complementing the Qur'an. Qādir opines that:

\section{Zakat is obligatory alms levied on certain kinds of property when it reaches a specified minimum quantity (Nisāb) and distributed to eight categories of person and purposes in the Muslim community (Quadri, 1981: 302).}

According to Encyclopedia of Qur'anic studies, zakat should not be considered merely as a device for ameliorating the lot of the poor and distributing wealth equitably. It is an important form of worship prescribed by Allah (Khan, 1987: 177). In the view of Raghib: zakat is wealth which is taken from the rich and given to the poor. It is being called zakat because it makes wealth grow or because the giving away of wealth is a source of purification (Ali. 1986: 462). In the 
perspective of Ahmad (1974: 78), he proclaimed that:

"Zakat is a legal alms tax which is levied on the rich to provide social justice".

Al-Azhari posits that: It is a specified portion taken from a definite quantity of wealth upon its attainment of prescribed maturity where such is fully possessed by the proprietor for a complete year (Al-Azhari, 118).

From the aforementioned definitions, views postulated by different scholars, we can rightly conclude that, zakat is a portion of the property of a Muslim bestowed in alms as an obligatory charity, taken from the surplus of his wealth to be given to the indigent persons or destitute in the society.

The philosophy behind the institution of zakat is that wealth should not remain confined to only the privileged in the society. Islam decries and condemns amassing of wealth and hoarding it in the hands of few individuals, the Qur'ān proclaimed thus; Woe to every (kind of) scandalmonger backbiter. Who piles up wealth and keeps counting it. He thinks that his wealth would make him last forever. By no means, he will be sure to be thrown into that which breaks to pieces... (Quran 104:1-4).

\section{THE SIGNIFICANCE OF ZAKAT IN ISLAM}

The word zakat is also called Sadaqat when used in the general sense to mean obligatory as well as voluntary alms in the Qur'an and Hadith (Bello, 2003, 48). Major difference between zakat and Sadaqat is that, zakat is one of the pillars of Islam which is obligatory only on wealthy Muslims whose earnings reach the minimum amount $(N i s ̦ \bar{a} b)$ for the upkeep of the less privileged in an Islamic community while Sadaqat (voluntary alms) is a voluntary act of charity and humanitarian gesture which can be carried out by any person whether rich or poor at any given time or place without specification or limit and its rejection in no way can lead to excommunication from the fold of Islam.

It is an indubitable fact that both zakat and Sadaqat aim at ameliorating the economic condition of the poor and the needy, help to bridge the gap between the rich and poor, create love and spread the feelings of love and cooperation based on practical faith among individual of any given Muslim community (Bello, 49).

In the views of the four Madhaaib, zakat is ranked in importance immediately next to the prescribed devotional worship to the extent both were mentioned together in eighty-two Qur'anic verses (Sabiq, 1995: 247). Al-Qur'ān categorically lays a great emphasis on the reward of paying zakat. This is emphatically articulated in the following verse of the Glorious Book:

"The parable of those who spend their wealth in the way of Allāh is that of a grain of corn: it growth seven ears and each ear hath a hundred grains Allah gives manifold increase to whom he please." (Qur'an 2:261)

The Qur'an further recommends the institution of zakat as an act that must be done to seek the pleasure of Allāh. The Qur'ān asserts thus:

"And the parable of those who spend their wealth to seek the pleasure of Allāh and for the 
certainty of their souls is as the parable of garden on an elevated ground." (Qur'an $2: 265)$

When emphasizing on the significance of zakat in Islam, Manna has the following beautiful expression:

\begin{abstract}
Zakat is the pivot and hub of the Islamic public finance, which covers moral, social and economic spheres in the moral sphere it washes away greed and acquisitiveness, in the social sphere, it acts as a unique measure vouchsafed by Islam to abolish poverty from the society. In the economic sphere, it prevents the morbid accumulation of wealth in a few hands and to diffuse it before it assumes threatening proportions in the hands of its possessor (Manna, 1970: 284).
\end{abstract}

\section{ADMINISTRATION OF ZAKAT IN ISLAM}

The institution of zakat in Islam is not simply obligatory charity but a state institution or where there is Muslim state, a national institution. The individual is not at liberty to calculate and spend his zakat as he likes. It must be collected by the state or a national body assigned for the task and spent by the state. This is categorically illustrated in the following Qur'anic verse which commands Prophet Muhammad to collect zakat thus:

"Take of their wealth alms to purify and cleans them there by..." (Qur'an 9:103)

In an Islamic state, the government is empowered to collect zakat from Muslim citizens who are willing to pay voluntarily. The state is also authorized to declare Jihad war on any of its territories that refuses to pay zakat. Such was the first jihad waged after the demise of the Prophet (SAW) under the leadership of Abu-Bakr (Qardawi, 1977: 77). It is logical that anybody placed in position of authority is in total control of state treasury and thus it is expected of him to see to the welfare of the indigents and the less fortunate in the society.

It was reported in a Hadìth related by Ahmad that Anas said:

A man from the tribe of Tamim came to the Messenger of Allāh (SAW) and said. "O Messenger of Allāh, I have plenty of property, a large family, a great deal of money and I am gracious Host to my guests, tell me how to conduct my life and how to spend. The Prophet $(S A W)$ replied "pay zakat out of your property, for truly it is a purifier which purifies you and be kind to your relatives and acknowledge the rights of the poor, neighbor and the beggars (Sabiq, 249)

The above Hadīth is a good admonition to wealthy Muslims who do not want to give out zakat for the fear of becoming poor if they give out from their wealth.

\section{Administration of Zakat in Nigeria}

In a multi-religious nation like Nigeria, it is strongly believed that the entire Muslim populace could endorse a system of central collection and distribution of zakat. It is the responsibility of the Muslim leaders in this country to set up a reliable mechanism whereby zakat could be administered under a capable, independent, national body, which 
oversees the administration of zakat nationwide. This body should necessarily by virtue of their importance and responsibilities comprise of erudite Muslim scholars of Islamic jurisprudence, experienced and well exposed Muslim professionals like accountants, economists, human resource managers, public administrators of good standing, etc.

Ibn Abbās reported that when the Prophet sent Muadh bin Jabal to Yaman (as its governor), he said to him, you are going to a people of the scripture, invite them to accept Shahadah: that there is no other God except Allāh and I am His messenger. If they accept and affirm this tell them that Allāh, the Gracious One, has enjoined five prayers upon them during the day and night. If they accept that, tell them also that $\mathrm{He}$ has enjoined sadaqat upon their assets which will be taken from the rich among them and distribute to the poor (Al-Shawkani, 1973: 170). All these will create a strong basis to administer zakat at any given Muslim or Islamic society, be it big or small.

\section{Administration of Zakat in Lagos State}

It must be noted that there is no centrally constituted body working on administration and collection of zakat in the State due to its nature. However, in setting up a formidable administrative structure for the collection of zakat in Lagos State, committees should be formed at each local government level. The function of the State body will thus be to carry out the actual day to day running of the administration of zakat. At the state level, the committee may be divided into two sub-committees:

1. State sub-committee for collection of zakat

2. State sub-committee for disbursement of zakat
The duty of the first sub-committee is to:

a) Conduct a statistic of the Muslims in the state who are able to pay zakat

b) The kind of property they own

c) What should be their payable zakat

d) Collect it annually, twice a year or quarterly

e) Safekeeping of it until it is handed over to the State zakat for disbursement.

This subcommittee could have a number of departments, depending on the kinds of zakat available in the State such as:

a) Department of gold, silver and cash

b) Department of livestock or grazing

c) Department of farm produces such as grown fruits and mineral resources.

The duty of the second subcommittee is similar to that of social welfare. Their duty is to:

a) Carry out an extensive survey using the best available means of identifying those who are eligible for zakat

b) To identify their needs

c) How best those needs could be met

d) The amount needed and its

e) disbursement in the best manner.

f) The sub-committee could also have five departments for the poor and the needy who have no income

g) Responsible workers whose income cannot maintain their family

h) Debtors who are not blameworthy for their predicaments 
i) Refugees and political asylum seekers

j) Islamic propagators

People who are working on the zakat committee must be:

a) Muslims

b) Mature

c) Honest

d) Knowledgeable about zakat

e) Possess expertise for their work (Bello, 52).

It is noteworthy that the collection of zakat, in spite of the remuneration paid for it, is regarded as a meritorious endeavour in Islam. A Hadith of the Prophet as quoted by Ali corroborates this fact (Ali, 1986: 475):

"The collection of zakat is equal to one who takes part in Jihād".

Thus, the disbursement of zakat facilitates social justice in the society through an equitable distribution of wealth. This scheme confirms the unanimous opinion of the Muslim Jurists that catering for the welfare of the people and relieving them of hardship is the basic objectives of the Shari' 'ah and hence of the Islamic State (Arikewuyo, 2001: 17).

\section{Iba Housing Estate Zakat Foundation for Poverty Alleviation}

Poverty Alleviation Programme is one of the meritorious activities ever conducted by the foundation, as it has touched both individuals and groups within and outside the estate. The zakat and sadaqāt foundation commenced its operation in October, 2014, with the appointment of Alhaj Musibau Yakub and Ustaz Musa Zubair as the Pioneer General Manager and General Secretary respectively. Other operational managers of the foundation are Alhaj Umar Akhokia and Alhaji A.A. Oluwo
(Iba Housing Estate Zakat Report, 2017: 1). Within thirty-six months of operation, the foundation had realized Nine Hundred and Thirty Thousand, seven hundred and sixty-eight Naira, Nineteen kobo. (N930,768.19k) (2). However, a total amount of eight hundred and fifty thousand naira has been disbursed to four beneficiaries. The four beneficiaries impacted by Iba Housing Estate Zakat and Sadaqat foundation range from three health related cases for medical supports and one financial empowerment for business. These actually affected three poor widows and one poor orphan (3).

\section{List of Beneficiaries}

It has been stated earlier that the poverty alleviation programme had up to 4 beneficiaries which can be grouped into two categories.

1. Health Beneficiaries

\begin{tabular}{|c|c|c|}
\hline $\mathbf{S} / \mathbf{N}$ & Names & Amount \\
\hline 1 & $\begin{array}{l}\text { Alhaj Abdul } \\
\text { Gafar Rauf }\end{array}$ & $¥ 250,000$ \\
\hline 2. & $\begin{array}{l}\text { Mr. Kasali } \\
\text { AbdAllāh }\end{array}$ & $¥ 200,000$ \\
\hline 3. & $\begin{array}{l}\text { Bro. Sabe of E } \\
\text { Zone }\end{array}$ & $¥ 200,000$ \\
\hline
\end{tabular}

2. Empowerment

\begin{tabular}{|c|l|l|}
\hline S/N & Names & Amount \\
\hline 1. & $\begin{array}{l}\text { Bro. Abdul } \\
\text { Rahman at } \\
\text { Agboroko }\end{array}$ & \\
\hline
\end{tabular}

CHALLENGES BESETTING THE

PAYMENT, COLLECTION AND

DISTRIBUTION OF ZAKAT IN IBA LOCAL COUNCIL DEVELOPMENT AREA

Administration of zakat in Iba Housing Estate is beset with so many problems, some of which are connected with its 
payments, others with its collection, while some others are connected with its disbursement. In our opinion, the most critical of these problems are related to the payment of zakat because we cannot talk about the collection or disbursement of it, if it is not paid. For this reason, the agency has the responsibility for improving the awareness of Muslims of their obligation of paying zakat, which is the third pillar of Islam. The agency is equally responsible for the collection and distribution of zakat and sadaqat.

In the course of our research, the following are the challenges threatening the operation of the agency:

1. Ignorance is one of the major obstacles on the part of members of Iba Housing Estate to comprehend the reason why they should pay zakat from their wealth.

2. Members also did not accept or acknowledge the fact that all their properties including Gold should be valued and all added together to determine whether they are eligible to pay zakat or not.

3. Majority of Iba Housing Estate residents are retirees who do not have major business to build more wealth.

4. The very gigantic and magnificent Central Mosque in Iba Housing Estate is still ongoing. The mosque committee has however confined the sources of income from members to only zakat. While Sadaqāt, Waqf and other forms of financial assistance, are forwarded to the Central Mosque which is under construction. Fund is not emanating from outside but from internal donation of members who are mostly pensioners with little money to sustain themselves, their family members and dependants (Ya'qub, 2017).

\section{ASSESSMENT OF IBA HOUSING ESTATE AGENCY ON COLLECTION OF ZAKAT FOR POVERTY ALLEVIATION}

It is a clear-cut fact that, the sources of income for the fund raised for the management of the agency is circumscribed to only zakat from members of the estate since the inauguration of the agency in 2014. This practice could not be sufficient to run such agency within the framework of poverty alleviation probably this could be one of the factors militating against the growth and development of the agency. Such agency would be enjoined to diversify its sources of income from other lawful means such as donations from philanthropists. It should not limit its sources of income to only zakat but sadaqat (voluntary donations from lawful means), waqf (endowments), hibbah (gifts) etc. Commenting on the overall impacts of the agency on the level of poverty reduction in South-West Nigeria, it is better to conclude that the scheme at such grassroots level with a little measure merely scratches the surface of the problem. The agency for now according to our submissions in this paper lacks the resources to achieve the aims and objectives for which it was founded for the Muslim ummah. In other words, the agency still has a long way to go in order for it to make any reliable and notable impacts on the lives and welfare of Muslims in Iba LCDA. 


\section{RECOMMENDATIONS}

The following recommendations according to our submissions in this paper may thus go a long way in increasing the positive impacts of the zakat agency on the poor and needy Muslims in Iba Local Council Area, Lagos State Nigeria.

a) There is need to embark on an effective orientation, sensitization, and public awareness campaign programmes by Iba Zakat Agency, on the need for the wealthy Muslims to be paying their zakat as appropriate.

b) Poverty reduction fund should not be confined to zakat payment alone, but should include other lawful sources of donors.

c) A sub-committee on zakat collection and distribution should be set up among the Ratibi mosques in Iba Local Council Development Area.

d) The poor and the needy members of the Muslim community should be motivated and encouraged to work harder in order to improve their lots.

e) To ensure effective collection and distribution of zakat, there should be transparency in the agency operation.

f) Muslims of more commendable and reliable social status should be appointed into the agency; this will also motivate the payment of zakat.

g) Zakat collection and payment should be computerized as we are living in a modern world which calls for advanced technology system.

h) The agency should introduce a corporate style of management in zakat collection in order to increase number of zakat payers as well as collectors.

i) The agency can employ the use of the social media in reminding as well as communicating with members of the Muslim Community and make them see the significance of paying zakat through special letters, sermons and text messages at different intervals.

\section{CONCLUSION}

The doctrines of zakat in Islam introduced the first system of social security and welfare, but in practice, zakat has been provided a marginal position in our society. This paper has assessed the dynamic application of zakat employed by Iba Housing Estate Zakat Agency since its inception. Despite the beautiful teachings of Islam, which address poverty alleviation, the efforts of Muslims in Iba Housing Estate in this regard, leave less to be desired. A study on their administration of zakat indicates that, it has limited sources of zakat revenue, even though it is situated amidst pensioners as well as low income earners, but the fact that they are force to be reckoned with in the community, necessitated the aptness of this study.

Given the challenges facing the agency which include low sources of income, unwillingness to pay zakat, insufficient orientation on the significance of zakat and its spiritual rewards to the donors, it could be said that the foundation has achieved some successes in ameliorating the suffering of the poor few Muslims in the locality. Its opportunities therefore lay in the number of proposals it sends to donor contributors. However, with the dominance of Muslims in the estate, the 
agency needs to devise more meaningful and workable strategies for sourcing of funds for the growth of the schemes. It is our believe that if all the issues and observations raised in this small piece are taking very seriously by the Iba Housing Estate Zakat Agency, Islam and Muslims in this locality would become a formidable force to reckon with among their peers and adherents of other faiths.

\section{REFERENCE}

Ahmad, S.M. 1974. Economics of Islam: A Comparative Study. Lahore-Pakistan SH. Muhammad Ashraf.

Al-Azhari, S.S. Jawahir al-Iklil Sharh Mukhtasar al-Khalil fii Madhaab Imam Malik. Egypt, Shaqruni Publishers, n.d.

Ali, M.M. 1986. The Religion of Islam. New Delhi, India, Taj Company.

Ali, M.M. 1986. The Religion of Islam, New Delhi, India, Taj Company.

Al-Shawkani, M.A. 1973. Naylu alAwar Min Akhbar Sayyid alAkhyar, Beirut, Dar al-Jil.

Al-Qardawi, Fiqh al-Zakah, Beirut, Darul fikr, 1977, vol. 1, 77.

Arikewuyo, S.I. 2001. Principles of Zakah and Wirathah, "A Mechanism for Social Justice in Islam", in Journal of the Nigeria Association of Teachers of Arabic and Islamic Studies (NATAIS) vol. 6, No. 1, Ijebu-Ode, Shebiotimo Publication.

Bello, I.A. 2003. "The Institution of Zakah and Its Administration in Nigeria: Problems and Prospects", in Amidu Sanni ed. An Unfamiliar
Guest in a Familiar Household in Honour of Isaac Adejoju Ogunbiyi, Bariga, Lagos, Debo prints.

Iba Housing Estate Zakaat Agency end of Term Report, 2014-2017.

Interview with Alhaji Ya'qub Musibau, Chairman of Iba Housing Estate Zakaat Foundation, Aged 55, December 22, 2017, at Iba Housing Estate Central Mosque.

Khan, M.R. 1987. Encyclopedia of Qur'anic Studies. New Delhi, India. Anmol Publications, PVILTD.

Manna, M.A. 1970. Islamic Economics: Theory and Practices. Lahore, Pakistan, Ashraf Press.

Mikail, A.S. 1997. "A Reflection on the Phenomenon of Poverty in Nigeria and the Islamic Framework for Reform, in alIjtihad: The Journal of Islamisation of Knowledge and Contemporary Issues, vol. 1, No. 2

Qadri, A.A. 1981. Islamic Jurisprudence in the Modern World. Lahore, Muhammad Ashraf.

Ritchie, J.M. 1976. Encyclopedia of the Holy Qur'an, Zakat (purification) New Delhi, India, Global Vision Publishing House, vol. 5.

Sabiq, S. 1995. Fiqh al-Sunnah. Beirut, Dar al-Fikr, 1995, vol.1.

Paramole, Kabir Olawale, PhD, FICA

Associate Professor

Department of Religions and Peace

Studies, Lagos State University

waleparamole@yahoo.com 
